\title{
The Moslema entrepreneurship and product innovation: Its impact on market orientation and performance of small and medium enterprises
}

\section{Ade Octavia*; Dahmiri Dahmiri; Panggita Wijaya; Yayuk Sriayudha}

Master of Management Program, Universitas Jambi, Indonesia

*To whom correspondence should be addressed.Email: ade_octavia@unja.ac.id

\begin{tabular}{|l|l|l|l|l|}
\hline DOI: & Received: & Revised: & Accepted: & Published: \\
10.22437/ppd.v8i4.10702 & 18.09 .2020 & 05.11 .2020 & 05.11 .2020 & 07.11 .2020 \\
\hline
\end{tabular}

\begin{abstract}
The development of entrepreneurship in a country is inseparable from the participation and role of women.Women's participation as an entrepreneur has increased quite sharply over the past decade and it turns out that the role is increasingly significant not only in developed countries but also in developing countries. This research aims to analyze the influence of Moslema entrepreneur and product innovation on market orientation and performance of SMEs.The research design uses a sample survey design with a quantitative approach. The population of this study is Islamic women entrepreneur who engaged as business owner called Moslema entrepreneur. Total sample amount of 86 people. The data analysis tool uses pathways analysis. The results showed that there is a significant influence between product innovation on performance and entrepreneurship on performance. Meanwhile this study stated that market orientation variables do not act as intervening variables. Thus, Moslema entrepreneurship needs to improve to increase performance. Moslema entrepreneurs must always innovate in marketing their products to consumers. Moreover, this research is expected to contribute empirically to strategic decision-making by SMEs.
\end{abstract}

Keywords: Business performance, Innovation, Islamic entrepreneurship, Moslema entrepreneurship

JEL Classification: M00, L26

\section{INTRODUCTION}

In crisis time, Small and Medium Enterprises (SMEs) have a better level of resilience compared to large businesses. SMEs play an important role in driving economic growth, both in number and the quality of entrepreneurship. Its existence needs to be supported in growing continously. The development of entrepreneurship in a country is not separated from the participation and role of women. Octavia et al. (2017) found that women's entrepreneur participation has increased quite sharply over the past decade and continues to increase significantly in both developed and developing countries. The existence of women entrepreneurs in SMEs is the economic 
life reality of most people in Indonesia.The role of women micro-entrepreneurs in the Indonesian economy has gradually become increasingly as "goalkeeper" of the people's economy. Women's contribution to development is often considered disproportionate compared to men. In fact, in terms of economy, approximately 60 percent of 51.21 million Micro, Small and Medium Enterprises in Indonesia are managed or owned by women. In addition to absorbing about 91.8 million or 93 percent of the total workforce, women workers in the informal sector also account for 55 percent of Gross Domestic Product.Women as one of the human resources that every country has, should be used as one of the mediators of economic growth and development through entrepreneurship.The unique and distinctive character of women makes many of them run and organize entrepreneurship (Miftakhuljanah et al. 2016). Ludiya \& Maulana (2020) stated that there is an influence of entrepreneurial characteristics and innovation on business performance in fashion SMEs in Cimahi City. This result is in accordance with Nurseto's research (2016) that there is a significant influence between entrepreneurial characteristics and innovation on business performance both simultaneously and partially

The ability to innovate is a factor that can influence the excellence of sustainable competition (Chamsuk, 2015). Innovation is defined as the company's tendency to enable and support new ideas, experiments, and creative processes that can be new products, new services, or technological processes (Islam et al. 2011). Innovation is a process of organizational change and market bids that are key to winning markets and consumers so as to increase sustainable competitive advantage (Chamsuk, 2015; Monika et al. 2016). In line with this research, Reguia (2014) and Chamsuk (2015) stated that innovation plays a role in realizing competitive excellence.

Innovation capabilities and positioning products are variables that have a significant effect on competitive excellence (Octavia et al. 2020). These findings are in line with previous research, where increased innovation and enterprise are important conditions for the strength of competitive positions especially for small companies (Bubel, 2015; Monika et al. 2016; Chiu \& Chen, 2016). In the model found, innovation capabilities are not only related to innovation in the field of marketing, but also the ability of companies to innovate from organizational components such as strong commitment to company leadership and management. Both of these factors are still weaknesses for most SMEs. It can be one of the inhibitory factors in realizing competitive advantage while the potential of SMEs is very huge and the number is growing as well. This research aims to analyze the influence of Moslema inovativeness, product innovation and market orientation on the performance of SMEs.

\section{METHODS}

\section{Design and sample research}

The type of research used in this study is explanatory research with quantitative approaches. The research that explains causal relationships and tests the relationship between multiple variables through hypothetical testing or explanatory research. The population in this study was 600 Moslema entrepreneurs in Jambi City. The research sample was taken by using the purposive sampling technique. This technique is done by taking a sample from the population-based on certain criteria. The number of research 
samples was 86 people.

\section{Research instrument test}

As a research instrument, the questionnaire was used to collect primary data. Validity and reliability tests were carried out on the questionnaire to determine whether the questionnaire used was valid and reliable. The validity is content describes the suitability of data that being measured. Reliability testing uses consistency interval reliability techniques. A test is carried out by trying out the instrument only once and data obtained is analyzed. From the two tests, it was found that all indicators used were valid and reliable.

\section{Data analysis}

Analysis of data was running out by pathways analysis in order to assess causality relationships between variables or causal models that have been set before based on theory. The analysis of the pathway itself does not determine causal relationships and nor can't be used as a subtitution for researchers to look at causality relationships between variables.

Causality relationships between variables have been formed with models based on theoretical foundations. In order to obtain the path coefficient value of each Independent variable, first calculated the correlation between variables using the Pearson Product Moment correlation. After the correlation coefficient between variables is calculated, the coefficient of the path is subsequently calculated. The manual steps performed in the path analysis are as follows:

1. Create a correlation matrix between Independent and dependent variables

2. Calculate the Inverse correlation matrix for independent variables $\left(\mathrm{R}_{1}-1\right)$

3. Calculate the $\mathrm{P}_{\mathrm{yxi}}$ Path Coefficient ( $\mathrm{i}=1.2$ ),

4. Calculates $R_{2}\left(X_{1} X_{2}\right)$ which is the coefficient that states the total determination of $\mathrm{X}_{1} \mathrm{X}_{2}$ against $\mathrm{Y}$

5. Count $\mathrm{P}_{\mathrm{ye}}$

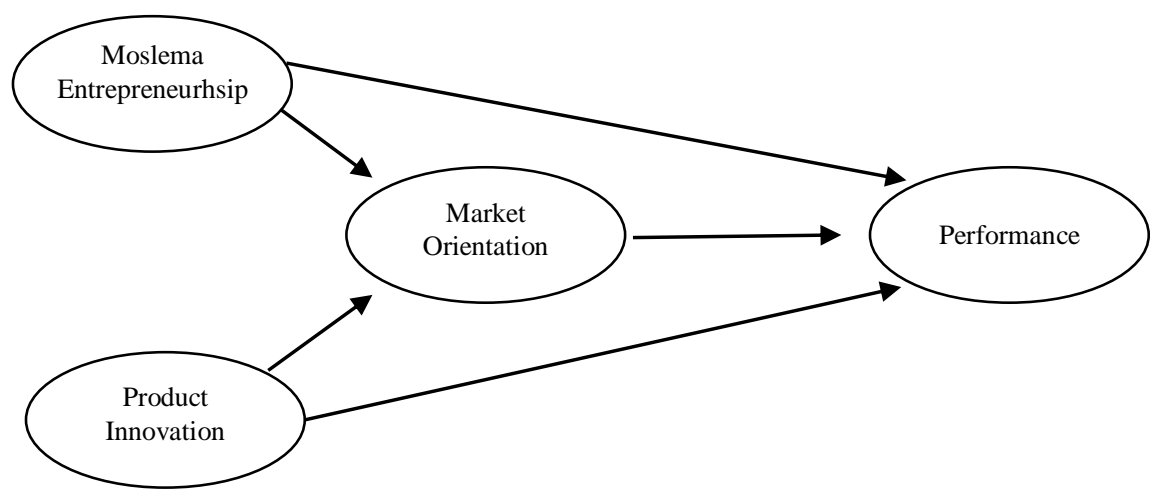

Figure 1. Research model

\section{RESULTS AND DISCUSSION}

Entrepreneurship is a concept that encompasses a way of thinking and acting within the organization. Entrepreneurship is a process for developing and realizing the vision and mission of business life by implementing innovative ideas and getting opportunities to run things. Moslema entrepreneurs have a unique characteristics that 
possible to be innovative for reaching market orientation and business performance.

Hypothetical testing was conducted by Path analysis that is an extension of multiple linear analysis to estimate causality relationships between variables (causal models) that have been set before based on theory. The analysis of the pathways themselves does not determine causal relationships and nor can it be used as a subtitution for researchers to look at causality relationships between variables. Causality relationships between variables have been formed with models based on theoretical foundations.

The results of testing between variables or hypotheses in this study were obtained from the results of running bootstrapping from the research model. If all coefficients in the confirmatory factor analysis model were statistically significant at $\mathrm{P}<0.05$, it will show the positive and significance relationship between those variables. Based on calculations, the $\mathrm{t}$-stat value is above the $\mathrm{p}$ value of 0,05 thus indicating the significant influence of each hypothesis.

Table 1. Results of analysis

\begin{tabular}{llccc}
\hline No & \multicolumn{1}{c}{ Path } & $\begin{array}{c}\text { Standard of } \\
\text { deviation }\end{array}$ & t statistic & P value \\
\hline 1. & Product Innovation - Performance & 0,125 & 0,402 & 0,688 \\
2. & Product Innovation - Market Orientation & 0,089 & 6,678 & 0,000 \\
3. & Moslema Entreperenurship - Performance & 0,094 & 3,554 & 0,000 \\
4. & Moslema Entrepreneurship - Market Orientation & 0,079 & 1,595 & 0,111 \\
5. & Market Orientation - Performance & 0,135 & 0,341 & 0,733 \\
\hline
\end{tabular}

Source: Data processed, 2020.

The results found that product innovation had no significant effect on performance (Table 1). Product innovation reflected by product quality, product variants and product style and design has no significant effect on the performance of SMEs reflected by sales growth, capital growth, labor growth, market growth, profit growth. Improvements by product quality, product variants and style and product design are incapable of sales growth, capital growth, labor growth, market growth, and profit growth.

The results of this study do not support the research that has been conducted by Utaminingsih (2016). The influence of innovation on marketing performance is evidenced by this research obtained by the value of sig. smaller than $\alpha=0.05$. To be suceed in the era of data and IT development, companies must innovate and interact with the market (Wang \& Ke, 2016; Chen, 2016; Tepic et al., 2017). This results is not in line with previously research that organizations with innovation capabilities can respond to environmental changes more quickly compared to non-innovative organizations that have high performance (Farsi et al., 2013; Asaad and Omer, 2016; Al-Refaie and Al-Taher, 2017). Besides, the goal of positioning a product is also to create a different image to introduce the product in the minds of consumers (Octavia et al., 2020).

From Table 1, product innovation has a positive and significance influence on market orientation of SMEs. Product innovation reflected by product quality, product variants and product style and design has a significant effect on market orientation reflected by customer orientation, competitor orientation, interfunctional coordination. The more attention to the positive loading factor value and significant value the higher 
product innovation will increase the orientation of the Market. On the other hand, the lower the product innovation will decrease the market orientation. This study supported by the previous researchers such as Chamsuk et al. (2015) and Reguia (2014).

This study obtained results that a value of significantly is smaller than $\alpha=0.05$. Moslema entrepreneurship has an effect and significant performance of SMEs in Jambi Province (Table 1). Increasing self-reliance, capital, emotional and education is able to increase sales growth, capital growth, labor growth, market growth dan profit growth. By paying attention to the positive loading factor and significant value, it can be concluded that the higher the Moslema entrepreneurship will improve performance the lower the Moslema entrepreneurship will decrease performance.

The results support research conducted by Ludiya \& Maulana (2020) which found that there is a positive influence of entrepreneurial characteristic variables on business performance. This means that the characteristics of entrepreneurship have a significant uni-directional positive influence, so the characteristics of entrepreneurship can explain the variables of business performance. The ups and downs of business performance can be determined through the level of entrepreneurial characteristics that business owners have. The better the characteristics of entrepreneurship then the performance of the business will increase. Moreover, entrepreneurship simultaneously has a significant effect on the success of performance. This means SMEs need to pay attention to independence, capital, emotional and education in order to improve performance. Some of the things that play a role in women's entrepreneurial success include stand-alone skills, risk-taking attitudes, competitiveness, innovation orientation and strategic plans (Agarwal et al. 2018 and Hodgkinson, 2001).

On the other hand, the test result of his study showed that moslema entrepreneurship has no significant effect on market orientation (Table 1). Contrary to prediction, although in line with the existing literature, there is no evidence to show relationship between moslema entrepreneurship and market orientation in SMEs. It is necessary for further research and take different variables that might interect each other. Moslema entrepreneurship reflected by self-reliance,capital, emotional and education has no significant effect on the market orientation reflected by customer orientation, competitor orientation, interfunctional coordination. This means that increase of selfreliance, capital, emotional and education is not able to improve customer orientation, competitor orientation, inter-functional coordination. This result is quite difference from previous research from Molovanovic \& Wittine (2014) that stated entrepreneurship imply active seeking and exploration of market opportunities in order to achieve above the average results.

Furthermore, market orientation had no significant effect on performance of SMEs .This means that increasing of customer orientation, competitor orientation, interfunctional coordination are not able to increase sales growth, capital growth, labor growth, market growth, profit growth. The results supported by the research that has been conducted by Ramadaniati \& Lestari (2020). Market orientation has no significant influence on the company's performance in the rattan industry. Meanwhile, the results of this study do not support the research that has been conducted by Utaminingsih (2016) that observed the influence of market orientation on marketing performance. 


\section{CONCLUSION AND RECOMMENDATION}

\section{Conclusion}

In the related literatures, entrepreneurship can be captured by the proper to act and to behave toward competition, to pursue market opportunities, to innovate and bear to take risk. This researh explore the influence among moslema entrepreneurdhip, innovation product, market orientation and performance of SMEs. As assumed by the hypothesis, in fact moslema entrepreneurship has no significant influence on market orientation, but it has an impact on business performance.

The more Moslema businesses have an entrepreneurial spirit, the more business performance will increase. On the other hand product innovation has a significant influence on market orientation, but didn't have an impact on business performance. Thus innovation must be continuously carried out. Consumers will see that products have a difference each other so as to increase consumers' buying interest. Furthermore, market orientation does not have an influence on business performance. For moslema entrepreneur, product marketing has not really adopted the strategy as measured in the market orientation instrument. However, by innovating products and having an entrepreneurial spirit, business performance can be achieved.

\section{Recommendation}

Considering for Moslema entrepreneurs to improve product innovation by improving product quality, product variant style and product design. With certain strategies, it is expected to further increase the market orientation continuously and strengthen the entrepreneurial spirit so as to increase business performance such as sales growth rate, capital growth, labor growth, market growth and profit growth.

\section{ACKNOWLEDGMENT}

We would like to thank to The Program of Master Management from The Faculty of Economics and Business, Universitas Jambi for providing us with the time and support to collaborate on this project.

\section{REFERENCES}

Agarwal, S., Agrawal, V. \& Agrawal, A.M. (2018). Motivational and Success Factors: Through the Lens Of Women Entrepreneurship. Int. J. Management and Enterprise Development, 17(4), 307-328.

Al-Refaie, A. \& Al-Taher, M. (2017). Effects of Knowledge Management and Organizational Learning on Firms Performance. Journal of Nature Science and Sustainable Technology, 8(3). 369-392.

Assad, Z.A \& Omen, B.M.R (2016). How Does Information Technology Capability Shape the Relationship Between Organizational Culture and Innovation Capability in Manufacturing Sectors ?. 17 th International Scientific Conference on Economic and Social Development

Bubel, D. (2015). Management of Innovations on The Aspect of an Enterprises Organization and Creativity of Employees. International Journal of Arts and Science, 8 (2), 163-171.

Chamsuk, W., Phimonsathien, T. \& Fungsuwan, W. (2015). Research and development (R\&D) Capabilities and Innovation Capablity That Affect the Enterprises 
Competitive Advantage in The Thai Automotive Part Industry: SEM Approach. International Journal of Arts \& Sciences, 8(2), 441-457.

Chen,Si-Hua. (2016). The Influencing Factors of Enterprise Sustainable Innovation: An Emprirical Studi. Sustainability, 8,(428), 1 - 17.

Chiu,Chia-Nan \& Chen, Huei-Huang. (2016). The Study of Knowledge management Capability and Organizational Effectiveness in Taiwannese Public Utility: The Mediator Role of Organizational Commitment. Springer Plus, 5(1520),1-34.

Farsi, J.Y., Rezazadeh, A. \& Najmabadi, A.D. (2013). Social Capital and Organizational Innovation: The Mediating Effect of Entpreneurial Orientation, SSRN Electronic Journal, 13(2). 22 - 40

Hodgkinson, G.P. (2001). The psychology of strategic management: diversity and cognition revisited International Review of Industrial and Organizational Psychology, 16, 65-120.

Islam, M.A., M.Aktaruzaman, K., Abu, J., M.Syed Alam. (2011). Effect of Entrepreneur and Firm Characteristic on the Business Success of Small and Medium Enterprises (SMEs) in Bangladesh. International Journal of Business and Management, 6,(3), 289 - 299.

Ludiya, E., \& Maulana, A. R. (2020). Pengaruh Karakteristik Wirausaha dan Inovasi Terhadap Kinerja Usaha Pada UMKM Fashion di Kota Cimahi. KINERJA, 17(1), 113-120.

Miftakhuljanah, O., Priatna, W.B. \& Suharno (2016). Karakter Wanita Wirausaha Pada Indistri Kecil Kerupuk Kemplang di kabupaten Ogan Ilir. Jurnal Agribisnis Indonesia, 4(2), 123-136.

Milovanovic, B,M. \& Wittine, Z. (2014). Analysis of External Environment's Moderating Role on the Entrepreneurial Orientation and Business Performance Relationship among Italian Small Enterprises. International Journal of Trade, Economics and Finance, 5(3), 224-229.

Monika, S., Andrzej, S., \& Malgorzata, O. (2016). Barriers for Cooperation Between Small Entreprises and Their Environment The Context of Innovativeness Polish Small Enterprises. 18th International Scientific Conference on Economic and Social Development-"Building Resilient Society.

Nurseto, S. (2016). Pengaruh Saluran Distribusi dan Promosi Terhadap Kinerja Pemasaran (Studi Kasus Pada UKM Furniture Kota Semarang). Jurnal Administrasi Bisnis, 5(2), 121-126.

Octavia, A., Zulfanetti, Z., \& Erida, E. (2017). Meningkatkan Daya Saing Daerah Melalui Peningkatan Kinerja Bisnis Usaha Mikro, Kecil dan Menengah di Provinsi Jambi. Jurnal Perspektif Pembiayaan dan Pembangunan Daerah, 4(3), 155-166.

Octavia, A., Sriayudha, Y \& Ali, H. (2020). Innovation Capability and Supply Chain Management: Empirical Study of Inodonesian Tradisional Herbal Medicine Product. International of Journal Supply Chain Management, 9(1), 601 - 608.

Ramadaniati, F., \& Lestari, D. (2020). Pengaruh Inovasi Pemasaran dan Inovasi Produk Terhadap Kinerja Pemasaran Syariah (Studi Empiris Pada Ukm Amplang di Samarinda). Jurnal Ilmu Ekonomi Mulawarman (JIEM), 4(4).

Reguia,C. (2014). Product Innovation and the Competitive. Europian Scientific Journal, Special Edition Vol. 1, 140-158. 
Tepic, M., Fortuin, F., Kemp, Ron.G.M \& Omta, O. (2014). Innovation Capabilities in Food and Beverages and Technology-based Innovation Project. British Food Journal, 16(2), 208 - 250.

Utaminingsih, A. (2016). Pengaruh Orientasi Pasar, Inovasi, dan Kreativitas Strategi Pemasaran Terhadap Kinerja Pemasaran Pada UKM Kerajinan Rotan di Desa Teluk Wetan, Welahan, Jepara. Media Ekonomi dan Manajemen, 31(2), 77 - 87

Wang, W.C \& Ke,Y.Z. (2016). Market Turbulence, Entrepreneurial Orientation and Explorative Innovation: The Role of Organizational Capabilities. Review of Integrative Business \& Economics Research, 5(1), 94-107.

(C) 2020 by the authors. Licensee JPPD, Indonesia. This article is an open-access article distributed under the terms and conditions of the Creative Commons Attribution (CC BY) license (http://creativecommons.org/licenses/by/4.0/). 